Matthew E. Gordley

\title{
The Colossian Hymn in Context
}

\section{An Exegesis in Light of Jewish and Greco-Roman Hymnic and Epistolary Conventions}

[Der Kolosserhymnus im Kontext. Eine Auslegung im Horizont jüdischer und griechisch-römischer Hymnik und Briefkultur.]

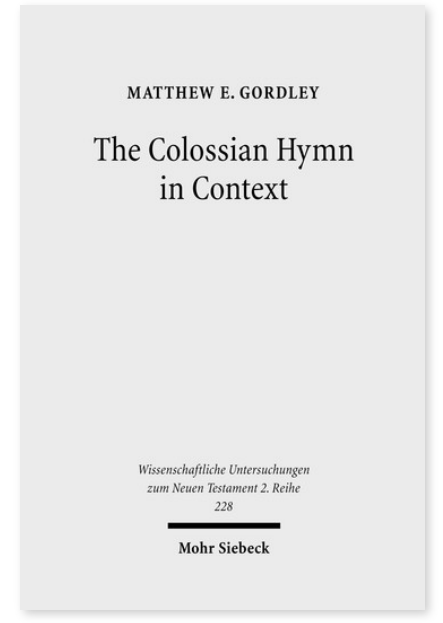

2007. IX, 295 Seiten. WUNT II 228

ISBN 978-3-16-151571-2

DOI 10.1628/978-3-16-151571-2

eBook PDF 79,00€

ISBN 978-3-16-149255-6

fadengeheftete Broschur 79,00€
Veröffentlicht auf Englisch.

Matthew E. Gordley untersucht den Kolosserhymnus im Horizont seines kulturellen und brieflichen Kontexts und zeigt, daß Kol. 1,15-20 einen Prosa-Hymnus zitiert, der in Verschmelzung jüdischer und griechisch-römischer Konventionen eine erhöhte Figur preist. Der Autor gibt einen Überblick über Hymnen in der frühjüdischen und griechisch-römischen Literatur und zeigt, daß der Kolosserhymnus in beiden Traditionen verwurzelt ist. Die formale und inhaltliche Analyse macht deutlich, daß der Hymnus ein quasi philosophischer Prosahymnus ist, der im Kontext eines paraentischen Briefes zitiert wird. Wie die rhetorische Analyse zeigt, erfüllt der Hymnus einer Reihe von wichtigen rhetorischen Funktionen im verbleibenden Teil des Briefes.

Matthew E. Gordley Born 1972; 2000 MDiv, Alliance Theological Seminary; 2006 PhD, University of Notre Dame; currently Dean of the College of Learning and Innovation, Carlow University (Pittsburgh, Pennsylvania).
Jetzt bestellen:

https://mohrsiebeck.com/buch/the-colossian-hymn-in-context-9783161515712?no_cache=1 order@mohrsiebeck.com

Telefon: +49 (0)7071-923-17

Telefax: $+49(0) 7071-51104$ 